شبكة مثلثية مقترحة (DSP) للخواص الفيزيائية الدالة للصخور واستخداماتها الممكنة

$$
\begin{aligned}
& \text { محمد قاسم حسن الجميلي } \\
& \text { قسم علوم الارض } \\
& \text { كلية العلوم }
\end{aligned}
$$

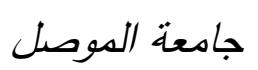

$$
\begin{aligned}
& \text { ( تاريخ الاستلام } \\
& \text { الملخص }
\end{aligned}
$$

تعد الخواص الفيزيائية الدالة للصـخور، خصوصـا الكثافة (D) والوزن النوعي (S) والمسـامية (P)، خواصسا مهمة في علاقتها بالمقاومسة الصخرية. لقد حاولت هذه الدراسـة دمـج هذه الخواص الثالثة وحسب العلاقات الرياضية بينها في شبكة منلثية اطلق عليها اسم (DSP). يمكن استخدام هذه الثبكة المثلثية اولا لتوضـيح التأثيرات الناتجـة عـن العلاقـات المتداخلـة بـين الخصـائص الفيزيائيـة المميـزة للصــور ، ان هـذا الاستخدام يتضمن قواعد علمية لدراسة العلاقة بين الخواص الفيزيائية والمقاومة الميكانيكية للصخور • وثانيا لتمثيل وتقدير الخواص الفيزيائية لعينات الصخور المختلفة. وثالثا لتصنيف الأنواع الصخرية المختلفة إلى الى مجاميع متباينة. يعبر عن كل مجموعـة برمز يتألف من ثنالثة أحرف أبجديـة. ورابعا لتوقع مدى ملاعمـة الصـخور للاستعمالات المتعددة في صـناعة البناء. هذا الاستخدام قد استتد على الانطقة الاربعـة والتي قسمت اليها الشبكة المثلثية. اختبرت القابلية التطبيقية لهذه الثبكة المثلثية المقترحة ووجد ان النتائج كانت مقنعة تماما.

\title{
A Proposed Triangular Net (DSP) for Index Physical Properties of Rocks and Its Possible Uses
}

\author{
Mohammad Q. H. Al-Jumaily \\ Department of Geology \\ College of Science \\ Mosul University
}

\section{ABSTRACT}

Index physical properties of rocks, particularly density (D), specific gravity (S) and porosity (P), formed an important relation to rock strength. This study attempts to integrate these three properties, according to their relationships through 
triangular net called (DSP). This triangular net can be used first to elucidate the resultant effects of interrelations of physical characteristics of rocks, and to predicate a scientific rules to study the relation between physical properties and mechanical strength of rocks. Second to represent and estimate the physical properties of various rock specimens. Third to classify different rock types into different groups. Each group is assigned a symbol that consists of three alphabetical letters. Fourth to estimate the suitability of rocks for various uses in the building industry. This use is based upon the zones into which the triangular net was divided. The applicability of this proposed triangular net is tested and the results found quite satisfactory. 